\title{
Basal ganglia calcifications (Fahr's syndrome): related conditions and clinical features
}

\author{
Giulia Donzuso $^{1} \cdot$ Giovanni Mostile $^{1} \cdot$ Alessandra Nicoletti $^{1} \cdot$ Mario Zappia $^{1}$ [D
}

Received: 8 January 2019 / Accepted: 26 June 2019 / Published online: 2 July 2019

(C) Fondazione Società Italiana di Neurologia 2019

\begin{abstract}
Basal ganglia calcifications could be incidental findings up to $20 \%$ of asymptomatic patients undergoing CT or MRI scan. The presence of neuropsychiatric symptoms associated with bilateral basal ganglia calcifications (which could occur in other peculiar brain structures, such as dentate nuclei) identifies a clinical picture defined as Fahr's Disease. This denomination mainly refers to idiopathic forms in which no metabolic or other underlying causes are identified. Recently, mutations in four different genes (SLC20A2, PDGFRB, PDGFB, and XPR1) were identified, together with novel mutations in the Myogenic Regulating Glycosylase gene, causing the occurrence of movement disorders, cognitive decline, and psychiatric symptoms. On the other hand, secondary forms, also identified as Fahr's syndrome, have been associated with different conditions: endocrine abnormalities of PTH, such as hypoparathyroidism, other genetically determined conditions, brain infections, or toxic exposure. The underlying pathophysiology seems to be related to an abnormal calcium/phosphorus homeostasis and transportation and alteration of the blood-brain barrier.
\end{abstract}

Keywords Fahr's syndrome $\cdot$ Brain calcinosis $\cdot$ Basal ganglia $\cdot$ Hypoparathyroidism

\section{Introduction}

Basal ganglia calcifications are associated with a variety of neurological and metabolic disorders, and calcifications could be also frequent incidental findings on neuroimaging of asymptomatic individuals [1]. Indeed, a certain degree of calcification of basal ganglia can be considered "physiological" with aging, over 50 years, and it could be an incidental finding in $15-20 \%$ of asymptomatic patients undergoing computed tomography (CT) scan [2-4].

Even if this condition is traditionally known as Fahr's disease or Fahr's syndrome, Theodore Fahr was not the first to describe brain calcifications nor contribute significantly to the understanding of this disorder. He reported a case of an 81year-old patient with long history of dementia and postmortem evidence of calcifications in white matter, basal ganglia, and small cerebral arteries [5], probably due to calciumphosphorus abnormalities. Before him, in 1850, Delacour first

Mario Zappia

m.zappia@unict.it

1 Department “GF Ingrassia”, Section Neuroscience, University of Catania, Via Santa Sofia 78, 95123 Catania, Italy described the presence of vascular calcifications of basal ganglia in a 56-year-old man who clinically had stiffness and weakness of lower extremities with tremor [6]. Then, in 1855, Bamberger described the histopathological entity of calcifications in the thinner cerebral vessels in a woman who had mental retardation and seizures [7].

Over the years, a variety of names have been associated with this condition; in 1974, the term "idiopathic basal ganglia calcification" (IBGC) was used for the first time [8], reporting two cases of familial idiopathic basal ganglia calcifications exhibiting features of "dystonia musculorum deformans" and used for brain calcification of unknown origin. Then, as these calcifications tend to show a predilection for the dentate nuclei and basal ganglia, a descriptive term "bilateral striopallidodentate calcinosis (BSPDC)" has been suggested [9]. In 2013, the term "primary familial brain calcification" (PFBC) has been introduced referring to a genetically confirmed neurodegenerative disorder with calcium deposits in the basal ganglia and other brain regions, in absence of a secondary cause [10]. More than 100 kindreds and sporadic cases have been reported [10], and the estimation of the minimal prevalence of PFBC from population genomic data analysis ranged from $4.5 / 10000$ to $3.3 / 1000$, using different level of evidence for pathogenicity [11]. 
Very recently, the term "primary bilateral brain calcification" has been suggested for both inherited and sporadic cases, facilitating differentiation between primary and secondary forms, and encompassing the different anatomical distribution that can be found [12]. However, considering the relative novelty of this new suggested nomenclature, in this review, we decided to maintain PFBC as the main term referring to both inherited and sporadic forms.

On the other hand, the term "syndrome" has been suggested when a secondary, and potentially treatable, cause is found [13], and it has been associated with different conditions, especially endocrine diseases. In these conditions, metabolic dysfunctions lead to an abnormal calcium/phosphorus ratio with precipitation of colloids in cerebral vessels and composition of calcified deposits [14].

In this review, we aim to clearly describe conditions characterized by basal ganglia calcification considering primary and secondary forms. A radiological description, an approach to diagnosis, and management are also discussed.

\section{Search strategy and selection criteria}

References for this review were identified by searches of PubMed up to June 1, 2019, and references from relevant articles. The search terms BSPDC, PFBC, IBGC, brain calcification, Fahr disease, OR basal ganglia calcification were used. We carried out a second search that included all publications up to June 1, 2019, using search terms: hypoparathyroidism, parathyroid, thyroid surgery AND brain calcifications OR basal ganglia calcifications. There were no language restrictions and the the final reference list was generated on the basis of relevance to the topics covered in this review

\section{Neuroimaging features}

Since the advent of the head CT scan, the number of case reports of intracranial calcifications increased over time. CT and magnetic resonance imaging (MRI) are widely used in clinical practice to identify and quantify mineral deposition [15]. Calcified areas could be easily identified as hyperdense lesions on CT that is considered decisive for accurate diagnosis, while, studies differ in their reporting of calcium on routine MRI sequences $[15,16]$. Calcium is a diamagnetic substance that may appear bright at T1-weighted imaging [17], but, at higher concentrations, the intensity of the signal in calcium at T1-weighted imaging diminishes [18]. On the other hand, calcified lesions could appear hypointense/hyperintense in T2-weighted MR images, because of the presence of other minerals in the same areas and the difference in the composition of calcium deposits, such as zinc, manganese, iron, and magnesium [15, 19, 20]. Moreover, it has been suggested that hyperintense $\mathrm{T} 2$-weighted lesions may be due to a progressive inflammatory process involving brain structures, which could be cause and/or consequence of calcification itself $[15,21]$ (Fig. 1). Recently, some authors suggested that susceptibility-weighted images (SWI), a fully velocity compensated 3D gradient-echo (GE) MR sequence with high sensitivity for blood products and iron, could definitively recognize calcifications, appearing hypointense, with higher sensitivity compared with other MRI sequences [15].

Regarding lesions' distribution pattern and qualitative aspects, calcifications are typically bilateral and symmetrical, most frequently located in the basal ganglia, but also in dentate nuclei, thalamus, brain stem, centrum semiovale, and subcortical white matter [15]. Pathological lesions can be easily distinguished from age-related physiological calcifications of basal ganglia for their features: the latter are often small and faint, symmetrical and confined into the globus pallidus, whereas the first are more diffuse and extensive, involving also the putamen and the dentate nucleus, and usually show a coarse conglomerate pattern [22].

Cerebral scintigraphies can detect functional/metabolic abnormalities and evaluate the integrity of the nigrostriatal and striato-cortical pathways. Brain perfusion, positron emission tomography/computed tomography (PET/CT), and dopamine transporter single-photon emission computed tomography (DaT-SPECT) data showed conflicting results [9, 23-28]. In a case of Fahr's disease with frontal lobe-type dementia and hyperkinetic-hypotonic syndrome, characterized by intermittent mild dystonic movements of hands, facial grimacing, and reduced muscular tonus of the extremities, ${ }^{18} \mathrm{~F}$-fluorodeoxyglucose $\left({ }^{18} \mathrm{~F}\right.$-FDG) PET/CT showed reduced glucose uptake not only in putamen and globus pallidus but also in temporal and parietal cortices, bilaterally [23]. The authors suggested that the reduced glucose cortical uptake could be secondary to the impaired circuits' function involving the basal ganglia [23]. These findings were consistently confirmed by subsequent studies $[24,25,27,28]$ showing a perfusion deficit in basal ganglia regions detected by Tc-99m HMPAO brain perfusion [28] and by ${ }^{18}$ F-FDG PET [29] suggesting that calcifications could play a critical role in the pathogenesis of neuronal degeneration. Le Ber and coll [25] showed a significantly reduced ${ }^{18} \mathrm{~F}$-FDG uptake in striatal and cortical areas, including the precuneus, posterior cingulate, and superior temporal gyri, in patients with familial calcifications and cognitive and psychiatric symptoms.

Similarly, the evaluation of the dopaminergic system and striatal uptake showed heterogeneous results. In two patients with PFBC, ${ }^{18} \mathrm{~F}$-fluoro-L-dopa uptake did not reveal any difference between patients and control subjects suggesting no evidence of dysfunction of the nigrostriatal dopaminergic pathway [9]. Saito and coll [26] used PET with $\left[{ }^{11} \mathrm{C}\right]$-labeled 
Fig 1 Brain MRI showing T1-w hyperintensity in basal ganglia (a) and severe $\mathrm{T} 2 *$-GRE

hypointensities in the same regions (b). Brain CT scan showing diffuse symmetric calcifications involving basal ganglia (c), and dentate nucleus (d). GRE gradient recalled echo, FLAIR fluidattenuated inversion recovery
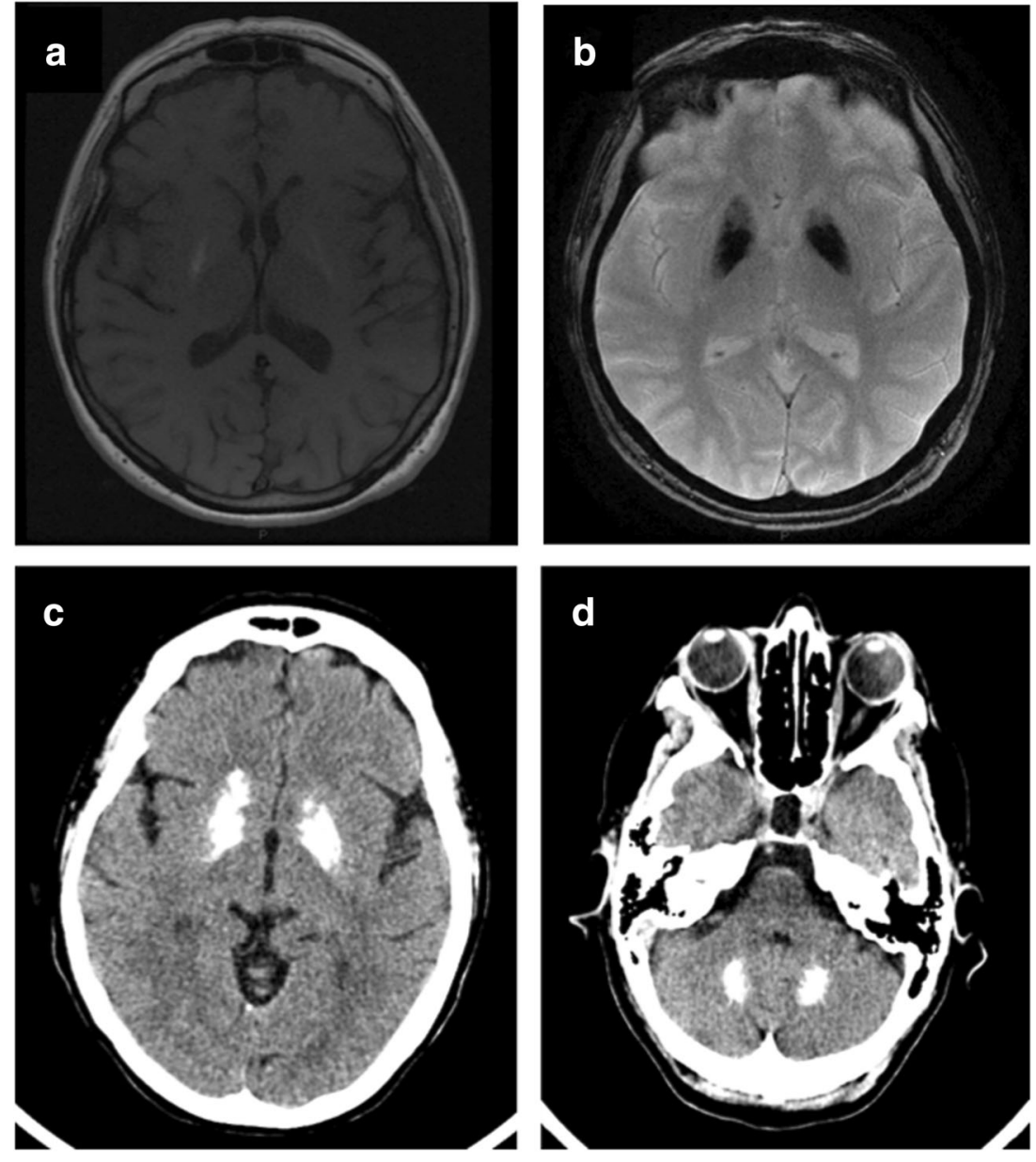

$2 \beta$-carbomethoxy-3 $\beta$-(4-flurophenyl)-tropane ( $\left.\left[{ }^{11} \mathrm{C}\right] \mathrm{CFT}\right)$, a ligand for the striatal pre-synaptic DA transporter, and $\left[{ }^{11} \mathrm{C}\right]$ labeled raclopride $\left(\left[{ }^{11} \mathrm{C}\right] \mathrm{RAC}\right)$, which binds DA D2 receptors and reflects postsynaptic DA function, in a case of PFBC with psychiatric symptoms and drug-induced parkinsonism. PET scanning showed a severe decline in pre- and postsynaptic dopaminergic function in bilateral striatum, suggesting the disruption of cortico-subcortical circuits [26]. Regarding DaT-SPECT with ${ }^{123}$ I-ioflupane and a possible nigrostriatal involvement, there were also conflicting results [27-29]. Two studies $[27,28]$ found a reduction in DaT binding in striatum regions in patients with basal ganglia calcifications presenting with parkinsonism and cognitive impairment; on the other hand, it has been reported normal striatal uptake, despite the presence of diffuse calcifications of basal ganglia documented bilaterally by a CT scan in patients with psychiatric symptoms and tremor [29] and with parkinsonism and cognitive impairment [30].

These results suggest that the different patterns of brain perfusion and dopaminergic function could be related to brain plasticity and neuronal adaptation to calcifications, leading to different structural and functional neuroimaging features.

\section{Neuropathology}

Recent neuropathological data suggest that PFBC is a disease of the cerebral microvessels, involving first vascular smooth muscles cells and pericytes. Moreover, very recently, hypodermal microvessel calcifications within and around the pericytes in the basal lamina in skin biopsies from patients with a genetic form of familial calcifications have been shown [31]. Histopathological studies showed that calcium is the major element present and it accounts for the radiological appearance of the disease, together with the involvement of several minerals like iron, magnesium, aluminum, and zinc [1, 32]. Macropathologic examination showed gray discoloration and gritty consistency of the posterior periventricular region, globus pallidus, putamen, and anterior thalamus and mild atrophy of the caudate nucleus, as well as in the cerebral cortex [33]. Reactive astrocytes and microglia accumulated around the calcified deposits, indicating a mild ongoing inflammatory process [34]. Calcifications were also observed in the tunica media of medium- and small-caliber arteries, arterioles, and capillaries leading to the obstruction of the lumen [35]. In addition, analysis of the blood-brain barrier showed that 
extravasation and perivascular deposition of fibrinogen was focally associated with areas of calcification [34]. Similar findings had been shown also in patients with brain calcifications due to pseudopseudohypoparathyroidism [36] and longstanding hypoparathyroidism [37], suggesting a common neuropathological pathway involving pericytes and endothelial environment both in primary and secondary forms.

\section{Classification}

In 2005, Manyam proposed a classification based on the anatomical sites where calcification occurred, identifying bilateral striopallidodentate calcinosis, striopallido ("basal ganglia") calcinosis, and dentate (cerebellar) calcinosis [1]. Otherwise, in order to identify possible biochemical abnormalities or reversible causes that result in deposition of calcium, a classification based on etiology has been proposed, i.e., primary/genetic forms of basal ganglia calcinosis, which includes autosomal dominant, familial and sporadic forms, and secondary forms associated with different diseases [1] (Table 1).

Table 1 Etiological classification of basal ganglia calcifications

\begin{tabular}{ll}
\hline $\begin{array}{l}\text { Primary forms } \\
\text { Gene }\end{array}$ & Chromosome position \\
SLC20A2 & $8 \mathrm{p} 11.21$ \\
PDGFRB & $5 \mathrm{q} 32$ \\
PDGFB & $22 \mathrm{q} 13.1$ \\
XPR1 & $1 \mathrm{q} 25.3$ \\
MYORG & $9 \mathrm{p} 13.3$ \\
Secondary forms & Calcium/phosphorus abnormalities \\
& - Idiopathic or secondary hypoparathyroidism \\
& Infections (brucellosis, AIDS, toxoplasmosis, \\
& TORCH complex) \\
& Toxic exposure (lead, carbon monoxide) \\
& Disimmunopathies (SLE) \\
& Pseudohypoparathyroidism \\
Cockayne syndrome I and II \\
\\
Aicardi-Goutières syndrome \\
Mitochondrial diseases (MELAS, MERRF) \\
Coat's syndrome \\
Neuroferritinopathy, NBIA
\end{tabular}

SLC20A2, solute carrier family 20 member 2; $P D G F B$, platelet-derived growth factor beta; $P D G F R B$, platelet-derived growth factor receptor beta; XPR1, Xenotropic and Polytropic Retrovirus Receptor 1; $M Y O R G$, Myogenic Regulating Glycosilase; MELAS, mitochondrial encephalopathy, lactic acidosis, and stroke-like episodes; MERRF,

\section{Primary forms}

Primary form refers to PFBC. PFBC manifests as autosomal dominant, familial, and sporadic forms; in these cases, there is the absence of metabolic or other secondary causes. Sporadic forms might be due either to de novo mutations or to a mutation transmitted by an undiagnosed, asymptomatic parent $[1,2,38]$. Genetic analyses of large families affected by autosomal dominant brain calcifications identified 2 loci named idiopathic basal ganglia calcification (IBGC) 1, located in chromosome 14q48 [39] and IBGC 2, in chromosome 2q37 [40]. In the following years, mutations in three other genes have been found to cause the disease: solute carrier family 20 member 2 (SLC20A2) within the IBGC 3 locus, platelet-derived growth factor receptor beta (PDGFRB), and plateletderived growth factor subunit beta (PDGFB) subsequently designated as IBGC 4 and IBGC 5, respectively [41]. Additionally, mutations in Xenotropic and Polytropic Retrovirus Receptor 1 (XPR1) were identified and designated as IBGC $6[42,43]$. Recently, sequencing analysis revealed a linkage between IBGC 1 and IBGC 3 [44] and identified multiexonic SLC20A2 deletions in the IBGC2 kindred [45], so that IBGC 1 and IBGC 2, identified as false loci, now all map to the SLC20A2 gene (IBGC 3). SLC20A2, located at $8 \mathrm{p} 11.21$, encodes the inorganic phosphate transporter PiT-2, a transmembrane protein associated with phosphate homeostasis in various tissues, including the brain, and its mutations result in a reduction of phosphate transport [38]. Mutations in SLC20A2 gene are responsible for most cases identified so far and over 40 pathogenic variants have been reported in patients with PFBC [46, 47]. Microarray analysis provided evidence that the neuroanatomical pattern of expression for SLC20A2 is highest in the regions most commonly affected in PFBC, showing that globus pallidus had the highest expression among basal ganglia, followed by thalamus and cerebellum [48].

PDGFRB (5q32) and PDGFB (22q13.1) are involved in pericytes recruitment, blood-brain barrier regulation, and angiogenesis $[49,50]$. XPR1 (1q25.3) is a gene encoding a retroviral receptor with phosphate export function and involved in phosphate homeostasis [42]. Very recently, mutations in the Myogenic Regulating Glycosylase (MYORG) gene were identified as a novel genetic cause for autosomal-recessive PFBC in Chinese patients [51, 52]. MYORG gene encodes a glycosyl hydrolase involved in myogenesis and expressed throughout the brain, particularly in the cerebellum, but its role in the pathogenesis of PFBC is yet unknown [53].

A systematic review from 2012 (when genes for PFBC were discovered) to November 2016 collected 137 cases, of which 34 were familial, and showed that SLC20A2 was the most common gene involved in 75 out of 137 cases (54.7\%), 
followed by PDGFB (43 cases-31.4\%) and PDGFRB (13 cases-9.5\%). XPR1 gene mutations were present in 6 cases (4.3\%) [54]. Over the years, several case reports described mutation variants, with peculiar clinical presentation, in SLC20A2 [55-58], PDGFB [59, 60], PDGFRB [61, 62], and XPR1 [63, 64].

The clinical phenotype encompasses neurologic and psychiatric features. Neuropsychiatric symptoms could be present in the form of schizophrenia like psychosis, depression, and irritability, and patients with extensive calcification seem to exhibit a higher frequency of psychiatric disorders than patients with limited involvement of brain structures [10]. Neurologic disturbances are heterogeneous; movement disorders are more commonly described, but seizures, headache, and cerebellar symptoms may occur. Neuropsychiatric features are also variable and include cognitive impairment, mood disorders, psychotic symptoms, and obsessivecompulsive symptoms [38]. Table 2 shows the types and frequencies of symptoms in patients with genetically proven PFBC observed in three recent studies including sporadic and familial cases $[54,65,66]$. In particular, genotypephenotype analysis showed parkinsonism seemed to be more common in SCL20A2, occurring up to $70 \%$ of patients, with the involvement of basal ganglia, thalamus, and dentate nucleus $[65,66]$. Analysis of cases reported with PDGFB mutations had hyperkinetic movements up to $25 \%$ of cases, cerebellar symptoms and headache, but also psychiatric manifestations, with calcifications of basal ganglia and cerebellum, while PDGFRB abnormalities were associated with depression, cognitive impairment, and headache. XPR1 mutations showed cognitive dysfunction (66.7\%) with hyperkinetic movements and dysarthria and cortical calcifications [54]. Moreover, patients with an early onset presented most frequently with psychiatric or cognitive symptoms, while older patients exhibited mostly movement disorders [67]. Considering only movement disorders, parkinsonism was found up to $85 \%$, chorea in $19 \%$, tremor in $8 \%$, dystonia in $8-19 \%$, athetosis in $5 \%$, and orofacial dyskinesia in $3 \%$ of patients [66-68]. Furthermore, affected members of the same family with a novel SCL20A2 mutation presented with similar brain calcification distribution but different cognitive and behavioral signs [69]. Later, Ramos and coll [70], by screening the well-known PFBC genes in four cohorts from America and Europe, found known and novel mutations of SLC20A2, PDGFB, PDGFRB, and XPR1, confirming the higher prevalence of SLC20A2 as the major causative gene (up to $13 \%$ ) and, consistent with previous series, the most frequent symptoms were parkinsonism (52.3\% of symptomatic individuals), cognitive impairment (40.9\%), and psychiatric signs (38.6\%) [70].

Very recently, Guo and coll [64] described the mutational spectrum of the first four discovered causative genes in a series of PFBC in Chinese patients, including 35 families and 191 sporadic individuals. They found different prevalence of mutations and symptoms than those of previous studies [54, $65,66]$, underlining the heterogeneity of genotype-phenotype correlation. SLC20A2 mutations were found in $14.2 \%$ of all patients, while mutations in the other three genes were very rare, accounting for $0.9 \%$ of all patients, respectively. Among symptomatic patients (44.8\%), the most common symptoms

Table 2 Clinical features of patients with genetically confirmed primary familial brain calcification

\begin{tabular}{|c|c|c|c|c|c|c|c|c|c|c|}
\hline \multirow[t]{2}{*}{ No. of cases } & \multicolumn{3}{|c|}{57 cases (22 families) [51] } & \multicolumn{3}{|c|}{167 cases ( 25 families) [55] } & \multicolumn{4}{|c|}{137 cases (34 families) [47] } \\
\hline & $\begin{array}{l}\text { SLC20A2 } \\
24\end{array}$ & $\begin{array}{l}\text { PDGFB } \\
19\end{array}$ & $\begin{array}{l}\text { PDGFRB } \\
14\end{array}$ & $\begin{array}{l}\text { SLC20A2 } \\
119\end{array}$ & $\begin{array}{l}\text { PDGFB } \\
32\end{array}$ & $\begin{array}{l}\text { PDGFRB } \\
16\end{array}$ & $\begin{array}{l}\text { SLC20A2 } \\
75\end{array}$ & $\begin{array}{l}\text { PDGFB } \\
43\end{array}$ & $\begin{array}{l}\text { PDGFRB } \\
13\end{array}$ & $\begin{array}{l}\text { XPR1 } \\
6\end{array}$ \\
\hline $\begin{array}{l}\text { Symptomatic } \\
\text { (\% within the mutation) }\end{array}$ & $17(70.8)$ & $11(57.8)$ & $5(35.7)$ & $71(59.7)$ & $23(71.9)$ & $7(46.7)$ & $57(76)$ & $32(74.4)$ & $6(46.1)$ & $6(100)$ \\
\hline Seizures ${ }^{\mathrm{a}}$ & $0(0)$ & $1(9.9)$ & $0(0)$ & $3(2.5)$ & $0(0)$ & $0(0)$ & $5(8.7)$ & $2(6.2)$ & $0(0)$ & $0(0)$ \\
\hline Cognitive impairment $\mathrm{t}^{\mathrm{a}}$ & $11(64.7)$ & $6(54.5)$ & $2(40)$ & $18(25.3)$ & $5(7)$ & $0(0)$ & $6(10.5)$ & $6(18.7)$ & $1(16.7)$ & $4(66.6)$ \\
\hline Parkinsonism $^{\mathrm{a}}$ & $12(70.6)$ & $3(27.3)$ & $2(40)$ & $16(22.5)$ & $3(13)$ & $2(28.6)$ & $16(28)$ & $3(9.3)$ & $1(16.7)$ & $38(0)$ \\
\hline Tremor $^{\mathrm{a}}$ & $6(35.3)$ & $2(18.2)$ & $1(20)$ & NA & NA & NA & $14(24.5)$ & $8(25)$ & $1(16.7)$ & $1(16.7)$ \\
\hline Dystonia $^{\mathrm{a}}$ & $6(35.3)$ & $2(18.2)$ & $1(20)$ & $22(30.9)$ & $7(30.4)$ & $0(0)$ & $10(17.5)$ & $4(12.5)$ & $0(0)$ & $0(0)$ \\
\hline $\begin{array}{l}\text { Ataxia/cerebellar } \\
\text { symptoms }^{\mathrm{a}}\end{array}$ & $1(5.9)$ & $2(18.2)$ & $1(20)$ & $7(9.8)$ & $4(17.4)$ & $2(28.6)$ & $6(10.5)$ & $6(18.7)$ & $0(0)$ & $1(16.7)$ \\
\hline Chorea $^{\mathrm{a}}$ & $1(5.9)$ & $1(9.1)$ & $1(20)$ & NA & NA & NA & $9(15.7)$ & $6(18.7)$ & $1(16.7)$ & $1(16.7)$ \\
\hline Dysarthria $^{a}$ & $5(29.4)$ & $3(27.2)$ & $1(20)$ & NA & NA & NA & $5(8.7)$ & $1(3.1)$ & $0(0)$ & $2(33.3)$ \\
\hline Headache $^{\mathrm{b}}$ & $6(25)$ & $5(26.3)$ & $3(21.4)$ & $16(13.4)$ & $14(43.8)$ & $3(20.0)$ & $3(4)$ & $14(32.5)$ & $3(23.1)$ & $0(0)$ \\
\hline Psychiatric symptoms ${ }^{\mathrm{a}}$ & $13(76.4)$ & $8(872.7)$ & $4(80)$ & $19(26.7)$ & $5(7)$ & $0(0)$ & $9(15.7)$ & $13(40)$ & $3(50)$ & $2(33.3)$ \\
\hline
\end{tabular}

Data shown as $n$ (\% within the mutation); ${ }^{\text {a } a m o n g ~ s y m p t o m a t i c ~ p a t i e n t s ; ~}{ }^{\mathrm{b}}$ among all patients. $N A$, not available; SLC20A2, solute carrier family 20 member 2; $P D G F B$, platelet-derived growth factor beta; $P D G F R B$, platelet-derived growth factor receptor beta; XPR1, Xenotropic and Polytropic Retrovirus Receptor 1 
were chronic headache (23.3\%), movement disorders (20\%), and vertigo (16.7\%); moreover, total calcifications score was related to clinical symptoms and was higher in patients with SLC20A2 mutations [64].

Differently from the other identified mutations, MYORG mutation carriers showed a very homogenous clinical presentation [71]. Dysarthria was present in $100 \%$ of symptomatic patients, together with the development of other features including akinetic-hypertonic syndrome (100\%), cerebellar syndrome (66.6\%), gait disorders, and pyramidal signs (86.6\%). Moreover, they showed a distinct radiological pattern including cerebellar atrophy and severe extensive calcifications involving the pons [71].

This wide spectrum of clinical presentation, even in the same pedigree in which individuals shared the same causing mutation, could be due to the different pathogenicity caused by different types of mutations, penetrance and expressivity, and "resilience" brain ability of individuals [72], and may depend on location of calcium deposits [54] but no obvious association between the site of calcification on CT and the type of clinical sign was observed [66]. Moreover, although Tadic and coll (2015) showed that penetrance of the imaging phenotype was $100 \%$, interestingly, almost a quarter of cases included in the analysis were asymptomatic, suggesting reduced penetrance of the mutations and/or incomplete reporting and/or unrecognized clinical symptoms and signs in carriers of mutations [66]. The spectrum of clinical symptoms of PFBC is further complicated by the presence of known mutations in a second gene that may contribute to or be entirely responsible for the disease manifestation [73], such as SLC20A2 and the neighboring THAP1 gene in a large dystonia family [74] or changes in the epilepsy-linked SCN2A gene in combination with SLC20A2 variants in PFBC patients with refractory seizures [75].

These data also support the evidence that genetic forms of brain calcification could be underestimated suggesting the importance of future studies in asymptomatic patients carrying genetic mutations.

\section{Secondary forms}

Secondary forms of brain calcifications have been associated with different conditions. In these cases, the term "Fahr's syndrome" has been proposed by some authors, to describe the heterogeneity of neuropsychiatric and neuroradiological features associated to the underlying causes $[1,54]$. The clinical history, examination, and laboratory findings are crucial for differential diagnosis. It is possible to identify secondary forms associated with endocrine disorders, especially hypoparathyroidism, leading to calcium/phosphorus abnormalities or other secondary conditions, such as infectious or toxic agents, when a documented exposition has been shown.

\section{Calcium/phosphorus abnormalities in hypoparathyroidism}

Calcium/phosphorus $(\mathrm{Ca} / \mathrm{P})$ ratio abnormalities, particularly due to parathyroid hormone (PTH) disorders, appear to be the most common definable etiology for calcification of white matter and bilateral subcortical nuclei [68]. The principal function of PTH is maintenance of calcium plasmatic levels, withdrawing the calcium from bone tissue, reabsorbing it from the glomerular filtrate, and indirectly increasing its intestinal absorption by stimulating active vitamin $\mathrm{D}$ (calcitriol) production [76]. Additionally, the PTH promotes an increase in urinary excretion of phosphorus and bicarbonate [77].

The most common causes leading to calcium homeostasis disorder include idiopathic or secondary hypoparathyroidism. Idiopathic hypoparathyroidism is an uncommon condition with a prevalence of 37 per 100.000 [78], characterized by the absence, fatty replacement, or atrophy of the parathyroid glands [13]. In a study of 147 patients with idiopathic hypoparathyroidism, 107 patients $(73.8 \%)$ showed basal ganglia calcifications on CT scan and its occurrence and progression were associated with low $\mathrm{Ca} / \mathrm{P}$ ratio [79]. On the other hand, long-term hyperphosphatemia could lead to down regulation of phosphate transporter in basal ganglia, thus determining colloid precipitation in cerebral blood vessels and brain calcification [14].

Secondary hypoparathyroidism is a relatively frequent complication of total or subtotal thyroidectomy with an incidence ranging from 6.9 to $46 \%$ for transient hypoparathyroidism, and from 0.9 to $1.6 \%$ for permanent hypoparathyroidism [76]. In an analysis of 170 consecutive patients undergoing primary total thyroidectomy, 41 patients $(24.1 \%)$ developed transient hypoparathyroidism and 2 patients $(1.2 \%)$ developed permanent hypoparathyroidism [80]. Epidemiological studies estimate the incidence of hypoparathyroidism related to neck surgery in the USA, which is reported in 7-36\% of surgeries, of which $38 \%$ are due to total thyroidectomy, $21 \%$ parathyroidectomy, $9 \%$ partial thyroidectomy, and 5\% other neck surgeries [78]. Consequently, the most common clinical scenario underlying basal ganglia and dentate nuclei calcifications is secondary hypoparathyroidism due to thyroid surgery with destruction or vascular compromise of parathyroid tissue, with an abnormal $\mathrm{Ca} / \mathrm{P}$ ratio, leading to hyperphosphatemia and hypocalcaemia [81]. Symptoms due to hypocalcaemia include paresthesia, cramps, spasm of carpal and pedal muscles, seizures, neuromuscular irritability, and ECG abnormalities such as prolonged QT interval and neurological signs [30, 82-92]. CT scan shows bilateral symmetrical calcifications involving basal ganglia, thalamus, corona radiata, and subcortical white matter and cerebellum [30, 82-92] and a variety of neurological signs and symptoms were described, such as seizures, loss of consciousness, falls, gait disturbances and postural instability, cognitive decline, parkinsonism, and rest tremor [30, 82-92]. Although calcifications of basal ganglia 
were present in all cases, clinical features were different and heterogenic suggesting that there is no clear correlation between brain areas involved and clinical signs.

\section{Infections}

Brain infections, such as brucellosis, acquired immune deficiency syndrome (AIDS), toxoplasmosis, but also intrauterine and perinatal congenital infections (toxoplasmosis, rubella, cytomegalovirus, or herpes simplex virus-TORCH complex) could determine brain calcifications [10]. Brucellosis is a zoonosis that affects animals as the primary host (e.g., sheep, goats) and humans as the secondary host. Neurobrucellosis occurs in 5-10\% of cases of brucellosis and affects the central or peripheral nervous system. This may lead to a variety of clinical manifestations and imaging abnormalities that mimic other neurologic diseases [93]. Brain calcifications are rare, involving basal ganglia, dentate nucleus, and white matter, and the detection in individuals residing in endemic areas should raise the possibility of brucellar infection involving the central nervous system [94].

Immunodeficiency caused by human immunodeficiency virus type 1 (HIV) determines a broad spectrum of clinical and pathological features. Pathologically, the terminal HIVinfected patient usually shows severe depletion of lymphoid tissue and opportunistic infections. Calcification is one of the most common pathological findings and involves blood vessels of multiple organs, including the brain [95]. Up to $33 \%$ of HIV-infected children show bilateral and symmetrical basal ganglia calcifications, involving putamen and globus pallidus and are usually not seen before 10 months of age [96]. In a retrospective autopsy study, $85 \mathrm{HIV}$-infected adult brains were examined and calcifications were observed in four cases $(5 \%$, calcific vasculopathy in three cases and parenchymal calcification in one case) [97].

Acute infection with Toxoplasma gondii usually is asymptomatic in children and adults, but serious clinical disease could result from a congenital infection. Infants with congenital toxoplasmosis are asymptomatic in about 70 to $90 \%$ of the cases, but they could develop sequelae during childhood or early adult life. A prospective study including 43 infants and children, with a confirmed diagnosis of congenital toxoplasmosis, showed diffuse intraparenchymatous calcifications in 28 children $(65 \%)$ and the presence of calcifications in the meninges and areas of the caudate nucleus indicates a poor prognosis [98].

\section{Toxic exposure}

Although the pathophysiological mechanism of brain toxicity related to chronic lead exposure is poorly understood, it has been suggested that a prolonged exposition could cause intracranial calcifications in adults [99]. Tonge and coll [100] showed microscopically a significant correlation between cerebellar calcification and increased lead levels in bones in 10 to $15 \%$ of autopsies performed between 1951 and 1976 . Neuroimaging findings include multifocal curvilinear calcifications in the subcortical white matter of both cerebral and cerebellar hemispheres and the involvement of basal ganglia, bilaterally [101]. A post-mortem neuropathological study on a 72-year-old man who was diagnosed with lead poisoning showed macroscopic and microscopic calcifications in the cerebellum, cerebral cortex, gray-white junction, white matter, basal ganglia, and thalamic regions. The pattern of calcification included deposits consisting of small calcospherites in the walls of the capillaries and in the tunica media of small- to medium-caliber vessels [102]. Basal ganglia calcifications involving globus pallidus may occur also in carbon monoxide poisoning [103].

\section{Disimmunopathies}

Systemic lupus erythematosus (SLE) is a chronic autoimmune multifactorial disease characterized by multisystemic involvement and diverse clinical features [104]. Involvement of the nervous system with cognitive and/or psychiatric, central, and peripheral nervous is referred to as neurolupus [105] and has been reported to be associated with brain calcification up to $30 \%$ of patients [106]. Brain CT scan showed the presence of diffuse calcifications over the basal ganglia, centrum semiovale, and cerebellum, and the involvement of the cerebral cortex [107-109].

\section{Other conditions}

Basal ganglia calcifications related to other genetically determined conditions occur mainly with other systemic signs or symptoms.

\section{Pseudohypoparathyroidism}

Brain calcifications can also occur in genetically determined forms of resistance to PTH defined as pseudohypoparathyroidism, in which clinical and laboratorial hypoparathyroidism findings (hypocalcemia, hyperphosphatemia) are associated with normal or high plasmatic levels of PTH that is normally produced [77]. This condition had been linked with mutation in GNAS (guanine nucleotide binding protein $\mathrm{G}$ alpha stimulating) and STX 16 (syntaxin), causing the occurrence of seizures, movement disorders with or without cognitive impairment, or psychiatric symptoms together with other clinical features such as short stature and skeletal abnormalities [110]. 


\section{Cockayne syndromes}

Cockayne syndrome (CS) type I (moderate CS) is characterized by basal ganglia calcifications, developmental abnormalities in the first two years, progressive impairment of vision, hearing, and central and peripheral nervous system functions leading to severe disability. CS type II (severe CS or early-onset CS) overlaps with cerebro-oculofacioskeletal syndrome (COFS) or Pena-Shokeir syndrome type I and it is characterized by growth failure at birth, with little or no postnatal neurologic development. Congenital cataracts or other structural anomalies of the eye may be present. CS type III (mild CS or late-onset CS) is characterized by essentially normal growth and cognitive development or by late onset [111].

Cockayne syndromes can result from mutations in either the excision repair cross-complementation group 6 (ERCC6) gene or the ERCC8 gene involved in repairing damaged DNA, but early reports found no obvious genotypephenotype correlations for mutations in either ERCC8 or $E R C C 6$, suggesting that the clinical variability within the CS spectrum may not be accounted for gene mutation alone [112]. CS is classified among the childhood leukodystrophies, and brain imaging findings are cardinal features suggesting the diagnosis of CS [113]. The main clinical findings are increased tone/spasticity, hyper- or hyporeflexia, abnormal gait or inability to walk, ataxia, tremor, seizures and behavioral abnormalities, and hearing and visual loss [111, 112, 114]. In patients with classic CS, symmetric, attenuated, and homogeneous putaminal calcifications are usually predominant, while in patients with severe CS II and COFS, diffuse cortical calcifications at the depths of the sulci are associated with the putaminal calcifications [113].

\section{Aicardi-Goutières syndrome}

Aicardi-Goutières syndrome (AGS) is a familial progressive early-onset encephalopathy characterized by physical and mental abnormalities, seizures, calcification of basal ganglia (particularly putamen, pallidus and thalamus), leukodystrophy, cerebral atrophy, and progressive microcephaly [115]. Crow and coll have identified mutations in 4 genes encoding the exonuclease TREX1 (AGS1) on chromosome 3 and all 3 subunits of the hetero-trimeric ribonuclease $\mathrm{H} 2$ (RNaseH2) endonuclease complex (AGS2 on chromosome 13, AGS3 on chromosome 11, AGS4 on chromosome 19) as responsible for the AGS phenotype [116]. These genes provide transcript for nucleases and absent or impaired enzyme function may result in the accumulation of unneeded DNA and RNA in cells [117]. In AGS, calcifications are more frequently small and punctuate in the basal ganglia and in the deep and periventricular white matter [118].

\section{Mitochondrial diseases}

Mitochondrial disorders could be characterized by abnormalities in calcium metabolism and high level of serum lactic acid. Mitochondrial encephalopathy, lactic acidosis, and stroke-like episodes (MELAS) and myoclonic epilepsy with ragged red fibers (MERRF) have been associated with calcification of the basal ganglia occurring up to $13 \%$ of cases [119]. MELAS is due an A-G point mutation at nucleotide 3243 (A3243G) in the tRNA ${ }^{\text {Leu }}$ gene of mtDNA (MTTL) [120]. A family with features of both MERRF and MELAS (MERRF/MELAS overlap syndrome) and a mutation in the gene MTTS1 (transfer RNA, mitochondrial, serine 1) whose members showed bilateral calcification of basal ganglia and cerebral atrophy has been described [121].

\section{Coat's disease}

Coat's disease is an eye disorder characterized by abnormal development of the retinal blood vessels. The underlying cause is not known but some cases may be due to somatic mutations in the NDP gene (Norrie Disease Pseudoglioma, encoding for a protein called norrin, participating in chemical signaling of cells) [122]. Goutières et al. described two children with bilateral Coats' disease associated with cerebral calcifications in the basal ganglia and deep white matter, asymptomatic at the time of their discovery [123].

\section{Neurodegenerative conditions}

Some neurodegenerative conditions such as neurodegeneration with brain iron accumulation (NBIA) and neuroferritinopathies could present basal ganglia calcification due to excess iron storage, neuroinflammation, or cystic degeneration, mainly in putamen or globus pallidus [13]. Recently, two cases of genetically confirmed pantothenate kinase-associated neurodegeneration (PKAN) with globus pallidus calcification have been described [124, 125]. Basal ganglia calcifications have also been described in two patients with beta propeller-associated neurodegeneration (BPAN), a recently characterized type of NBIA caused by mutations in the tryptophan-aspartic acid (W-D) dipeptide repeats domain 45 (WDR45) gene encoding for $\beta$ propeller protein, presenting with progressive dystonia and dementia and autistic regression and seizures, respectively. Neuroimaging findings showed the presence of bilateral dense calcification of globus pallidus revealed by $\mathrm{CT}$ scan together with symmetric MRI T2 hypointensity of bilateral globi pallidi and substantia nigra $[126,127]$. PKAN and other NBIA syndromes should be considered in the differential diagnoses of basal ganglia calcification especially when calcification is limited to the globus pallidus with early onset of neuropsychiatric features 
characterized by slowly progressive extrapyramidal signs and psychiatric symptoms [124, 125].

Recently, Shi and coll [128] recently described a novel mutation in Ras-related protein 39B (RAB39B) as a potential cause of $X$-linked juvenile parkinsonism with very early onset presenting with bilateral pallidum calcifications. RAB39B, a member of the RAS oncogene family, consists of 2 exons on the chromosome Xq28 and plays an essential role in neuronal maintenance and survival [128].

\section{Diagnostic approach}

The detection of bilateral basal ganglia calcifications on CT/ MRI investigations, together with a progressive neurologic dysfunctions, which generally includes movement disorders and/or neuropsychiatric manifestations, should start a diagnostic workup based on key points, orienting in the differential diagnosis between primary or secondary forms [1].

Since idiopathic or secondary hypoparathyroidism are the most common causes of basal ganglia calcification in adulthood, disorders of $\mathrm{Ca} / \mathrm{P}$ metabolism and parathyroid abnormalities should be excluded $[68,81]$. Specific blood test is crucial to exclude poisoning-related brain calcifications, infections, or autoimmune conditions [129]. If secondary causes are excluded and the family history is suggestive of autosomal dominant inheritance, molecular genetic testing should be considered [13]. SLC20A2 is the most common gene involved followed by PDGFB and PDGFRB [54]. Finally, age-related and asymptomatic physiological basal ganglia calcifications have been detected up to $20 \%$ of routine CT scan and the radiological pattern could distinguish them from pathological calcifications [3]. Usually, physiological calcifications involve the globus pallidus and are bilateral and faint; other regions that may be involved include the pineal gland, falx, and choroid plexus [129].

\section{Therapy}

Management strategies and treatment mainly focus on symptomatic relief and are strictly related to the clinical features. Since selective removal of deposited calcium from the brain without effecting calcium from bone and other tissues appears to be an impossible task [1], pharmacological treatment should be used to improve neurological and/or psychiatric symptoms and to try to remove underlying cause [10]. The presence of an abnormal $\mathrm{Ca} / \mathrm{P}$ metabolism or parathyroid dysfunction should be corrected with intravenous calcium gluconate or long-term oral therapy with calcium and calcitriol, with the improvement of extrapyramidal signs and chronic paresthesia or seizures in most cases [82, 86-88]. Additionally, appropriate antiepileptic drugs for seizures should be used
[89]. Antiparkinsonian drugs could be useful for patients with parkinsonism, even if pharmacological response could be minimal $[83,88,130]$. Patients who develop psychiatric features should be treated with mood stabilizer or antipsychotic drugs. Neuroleptic medication should be used cautiously, since they may exacerbate extrapyramidal symptoms, while a poor response to neuroleptics was obtained in a family with brain calcifications and psychotic manifestations [10]. Loeb et al. used disodium etidronate in one patient, determining symptomatic benefit without reduction in calcification [130]. Recently, a case series of 7 patients treated with alendronate showed good tolerance and evidence of improvements in symptoms (tremor and headache) and stability by some patients, suggesting the effectiveness of alendronate therapy in basal ganglia calcification [131].

\section{Conclusions}

Basal ganglia calcification is a rare neurodegenerative disorder occurring as primary/idiopathic disease or as secondary manifestation of a condition, leading to an abnormal deposition of calcium in peculiar brain structures. This condition is associated with a variety of neuropsychiatric signs and symptoms and could be unnoticed for years. Recently, genetic mutations have been identified helping in distinguish between idiopathic and secondary forms, associated with different conditions. Clinically, parkinsonism or other movement disorders appear to be the most common presentation, together with seizures and cognitive decline. CT scan is considered the gold standard for diagnosis identifying calcifications as hyperdense lesions typically bilateral and symmetrical, most frequently involving basal ganglia, but also dentate nuclei, thalamus, and subcortical white matter. The anatomical pattern of calcifications does not seem to be directly correlated to the clinical phenotype. Further studies are needed in order to clarify pathological mechanisms of calcium deposition and identify specific therapeutic strategies.

\section{Compliance with ethical standards}

Conflict of interest The author declares that she has no conflict of interest.

\section{References}

1. Manyam BV (2005) What is and what is not 'Fahr's disease'. Parkinsonism Relat Disord 11:73-80

2. Savino E, Soavi C, Capatti E, Borrelli M, Vigna GB, Passaro A, Zuliani G (2016) Bilateral strio-pallido-dentate calcinosis (Fahr's disease): report of seven cases and revision of literature. BMC Neurol 16:165 
3. Yamada M, Asano T, Okamoto K, Hayashi Y, Kanematsu M, Hoshi H, Akaiwa Y, Shimohata T, Nishizawa M, Inuzuka T, Hozumi I (2013) High frequency of calcification in basal ganglia on brain computed tomography images in Japanese older adults. Geriatr Gerontol Int 13(3):706-710

4. Simoni M, Pantoni L, Pracucci G, Palmertz B, Guo X, Gustafson D, Skoog I (2008) Prevalence of CT-detected cerebral abnormalities in an elderly Swedish population sample. Acta Neurol Scand 118(4):260-267

5. Fahr T (1930) Idiopathische verkalkung der hirngefässe. Zentrabl Allg Pathol 50:129-133

6. Delacour A (1850) Ossification des capillaires du cerveau. Ann Med Psychol 2:458-461

7. Bamberger, Von Rokitansky K (1856) Lehrbuch der Pathologischen Anatomie, vol 2. Wilhelm Braumuller, Vienna

8. Caraceni T, Broggi G, Avanzini G (1974) Familial idiopathic basal ganglia calcification exhibiting "dystonia musculorum deformans" features. Eur Neurol 12:351-359

9. Manyam BV, Bhatt MH, Moore WD, Devleschoward AB, Anderson DR, Calne DB (1992) Bilateral striopallidodentate calcinosis: cerebrospinal fluid, imaging, and electrophysiological studies. Ann Neurol 31:379-384

10. Sobrido MJ, Coppola G, Oliveira J, Hopfer S, Geschwind DH (1993-2014) Primary familial brain calcification. In: Pagon RA, Adam MP, Ardinger HH, Bird TD, Dolan CR, Fong CT et al (eds) GeneReviews $^{\mathrm{TM}}$. University of Washington, Seattle. Available from: http://www.ncbi.nlm.nih.gov/books/NBK1421/. Accessed June 2019

11. Nicolas G, Charbonnier C, Campion D, Veltman JA (2018) Estimation of minimal disease prevalence from population genomic data: application to primary familial brain calcification. Am J Med Genet B Neuropsychiatr Genet 177(1):68-74

12. Ferreira LD, Mendes de Oliveira JR (2018) The need for consensus on primary familial brain calcification nomenclature. J Neuropsychiatry Clin Neurosci 30(4):291-293

13. Saleem S, Aslam HM, Anwar M, Anwar S, Saleem M, Saleem A, Rehmani MA (2013) Fahr's syndrome: literature review of current evidence. Orphanet J Rare Dis 8(8):156

14. Shoback DM, Bilezikian JP, Costa AG, Dempster D, Dralle H, Khan AA, Peacock M, Raffaelli M, Silva BC, Thakker RV, Vokes T, Bouillon R (2016) Presentation of hypoparathyroidism: etiologies and clinical features. J Clin Endocrinol Metab 101(6):23002312

15. Valdés Hernández M, Maconick LC, Tan EM, Wardlaw JM (2012) Identification of mineral deposits in the brain on radiological images: a systematic review. Eur Radiol 22(11):2371-2381

16. Sahin N, Solak A, Genc B, Kulu U (2015) Fahr disease: use of susceptibility-weighted imaging for diagnostic dilemma with magnetic resonance imaging. Quant Imaging Med Surg 5(4): 628-632

17. Ginat DT, Meyers SP (2012) Intracranial lesions with high signal intensity on T1-weighted MR images: differential diagnosis. Radiographics 32(2):499-516

18. Henkelman RM, Watts JF, Kucharczyk W (1991) High signal intensity in MR images of calcified brain tissue. Radiology 179(1):199-206

19. Valdés Hernández M, Glatz A, Kiker AJ, Dickie DA, Aribisala BS, Royle NA, Muñoz Maniega S, Bastin ME, Deary IJ, Wardlaw JM (2014) Differentiation of calcified regions and iron deposits in the ageing brain on conventional structural MR images. J Magn Reson Imaging 40(2):324-333

20. Gronemeyer SA, Langston JW, Hanna SL, Langston JW Jr (1992) MR imaging detection of calcified intracranial lesions and differentiation from iron-laden lesions. J Magn Reson Imaging 2(3):271276
21. Avrahami E, Cohn DF, Feibel M, Tadmor R (1994) MRI demonstration and CT correlation of the brain in patients with idiopathic intracerebral calcification. J Neurol 241(6):381-384

22. Kıroğlu Y, Callı C, Karabulut N, Oncel C (2010) Intracranial calcifications on CT. Diagn Interv Radiol 16(4):263-269

23. Hempel A, Henze M, Berghoff C, Garcia N, Ody R, Schröder J (2001) PET findings and neuropsychological deficits in a case of Fahr's disease. Psychiatry Res 108(2):133-140

24. Ogi S, Fukumitsu N, Tsuchida D, Uchiyama M, Mori Y, Matsui K (2002) Imaging of bilateral striopallidodentate calcinosis. Clin Nucl Med 27(10):721-724

25. Le Ber I, Marié RM, Chabot B, Lalevée C, Defer GL (2007) Neuropsychological and 18FDG-PET studies in a family with idiopathic basal ganglia calcifications. J Neurol Sci 258(1-2): $115-122$

26. Saito T, Nakamura M, Shimizu T, Oda K, Ishiwata K, Ishii K, Isse K (2010) Neuroradiologic evidence of pre-synaptic and postsynaptic nigrostriatal dopaminergic dysfunction in idiopathic basal ganglia calcification: a case report. J Neuroimaging 20(2):189191

27. Paghera B, Caobelli F, Giubbini R (2013) 123I-ioflupane SPECT in Fahr disease. J Neuroimaging 23(1):157-158

28. Paschali A, Lakiotis V, Messinis L, Markaki E, Constantoyannis C, Ellul J, Vassilakos P (2009) Dopamine transporter SPECT/CT and perfusion brain SPECT imaging in idiopathic basal ganglia calcinosis. Clin Nucl Med 34(7):421-423

29. Calabria F, Ciccariello G, Falcone C, Cascini GL, Schillaci O (2015) A case of Fahr's disease examined by multi-modal imaging. Eur J Nucl Med Mol Imaging 42(13):2098-2099

30. Donzuso G, Sciacca G, Nicoletti A, Mostile G, Patti F, Zappia M (2016) Extensive bilateral striopallidodentate calcinosis: a 50 years history of hypoparathyroidism presenting like a parkinsonian syndrome. J Neurol 263(9):1876-1879

31. Nicolas G, Marguet F, Laquerrière A, Mendes de Oliveira JR, Hannequin D (2017) Microangiopathy in primary familial brain calcification: evidence from skin biopsies. Neurol Genet 3(2): e134

32. Smeyers-Verbeke J, Michotte Y, Pelsmaeckers J, Lowenthal A, Massart DL, Dekegel D, Karcher D (1975) The chemical composition of idiopathic nonarteriosclerotic cerebral calcifications. Neurology 25(1):48-57

33. Wider C, Dickson DW, Schweitzer KJ, Broderick DF, Wszolek ZK (2009) Familial idiopathic basal ganglia calcification: a challenging clinical-pathological correlation. J Neurol 256:839-842

34. Miklossy J, Mackenzie IR, Dorovini-Zis K, Calne DB, Wszolek ZK, Klegeris A, McGeer PL (2005) Severe vascular disturbance in a case of familial brain calcinosis. Acta Neuropathol 09(6):643 653

35. Kimura T, Miura T, Aoki K, Saito S, Hondo H, Konno T, Uchiyama A, Ikeuchi T, Takahashi H, Kakita A (2016) Familial idiopathic basal ganglia calcification: histopathologic features of an autopsied patient with an SLC20A2 mutation. Neuropathology 36(4):365371

36. Iwase T, Yoshida M, Hashizume Y, Yazawa I, Takahashi S, Ando T, Ikeda T, Nokura K (2019) Intracranial vascular calcification with extensive white matter changes in an autopsy case of pseudopseudohypoparathyroidism. Neuropathology 39(1):39-46

37. Preusser M, Kitzwoegerer M, Budka H, Brugger S (2007) Bilateral striopallidodentate calcification (Fahr's syndrome) and multiple system atrophy in a patient with longstanding hypoparathyroidism. Neuropathology 27(5):453-456

38. Lemos RR, Ramos EM, Legati A, Nicolas G, Jenkinson EM, Livingston JH, Crow YJ, Campion D, Coppola G, Oliveira JR (2015) Update and mutational analysis of SLC20A2: a major cause of primary familial brain calcification. Hum Mutat 36(5): $489-495$ 
39. Geschwind DH, Loginov M, Stern JM (1999) Identification of a locus on chromosome 14q for idiopathic basal ganglia calcification (Fahr disease). Am J Hum Genet 65:764-772

40. Volpato CB, De Grandi A, Buffone E, Facheris M, Gebert U, Schifferle G, Schönhuber R, Hicks A, Pramstaller PP (2009) 2q37 as a susceptibility locus for idiopathic basal ganglia calcification (IBGC) in a large South Tyrolean family. J Mol Neurosci 39:346-353

41. Taglia I, Mignarri A, Olgiati S, Menci E, Petrocelli PL, Breedveld GJ, Scaglione C, Martinelli P, Federico A, Bonifati V, Dotti MT (2014) Primary familial brain calcification: genetic analysis and clinical spectrum. Mov Disord 29(13):1691-1695

42. Legati A, Giovannini D, Nicolas G, Lopez-Sanchez U, Quintans B, Oliveira JR et al (2015) Mutations in XPR1 cause primary familial brain calcification associated with altered phosphate export. Nat Genet 47:579-581

43. Anheim M, López-Sánchez U, Giovannini D, Richard AC, Touhami J, N'Guyen L, Rudolf G, Thibault-Stoll A, Frebourg T, Hannequin D, Campion D, Battini JL, Sitbon M, Nicolas G (2016) XPR1 mutations are a rare cause of primary familial brain calcification. J Neurol 263:1559-1564

44. Hsu SC, Sears RL, Lemos RR, Quintáns B, Huang A, Spiteri E, Nevarez L, Mamah C, Zatz M, Pierce KD, Fullerton JM, Adair JC, Berner JE, Bower M, Brodaty H, Carmona O, Dobricić V, Fogel BL, García-Estevez D, Goldman J, Goudreau JL, Hopfer S, Janković M, Jaumà S, Jen JC, Kirdlarp S, Klepper J, Kostić V, Lang AE, Linglart A, Maisenbacher MK, Manyam BV, Mazzoni P, Miedzybrodzka Z, Mitarnun W, Mitchell PB, Mueller J, Novaković I, Paucar M, Paulson H, Simpson SA, Svenningsson P, Tuite P, Vitek J, Wetchaphanphesat S, Williams C, Yang M, Schofield PR, de Oliveira JRM, Sobrido MJ, Geschwind DH, Coppola G (2013) Mutations in SLC20A2 are a major cause of familial idiopathic basal ganglia calcification. Neurogenetics 14(1):11-22

45. Grütz K, Volpato CB, Domingo A, Alvarez-Fischer D, Gebert U, Schifferle G, Buffone E, Wszolek ZK, Rademakers R, Ferbert A, Hicks AA, Klein C, Pramstaller PP, Westenberger A (2016) Primary familial brain calcification in the 'IBGC2' kindred: all linkage roads lead to SLC20A2. Mov Disord 31(12):1901-1904

46. Taglia I, Bonifati V, Mignarri A, Dotti MT, Federico A (2015) Primary familial brain calcification: update on molecular genetics. Neurol Sci 36(5):787-794

47. Gagliardi M, Morelli M, Annesi G, Nicoletti G, Perrotta P, Pustorino G, Iannello G, Tarantino P, Gambardella A, Quattrone A (2015) A new SLC20A2 mutation identified in southern Italy family with primary familial brain calcification. Gene 568(1): 109-111

48. da Silva RJ, Pereira IC, Oliveira JR (2013) Analysis of gene expression pattern and neuroanatomical correlates for SLC20A2 (PiT-2) shows a molecular network with potential impact in idiopathic basal ganglia calcification ("Fahr's disease"). J Mol Neurosci 50(2):280-283

49. Keller A, Westenberger A, Sobrido MJ, García-Murias M, Domingo A, Sears RL, Lemos RR, Ordoñez-Ugalde A, Nicolas G, da Cunha JEG, Rushing EJ, Hugelshofer M, Wurnig MC, Kaech A, Reimann R, Lohmann K, Dobričić V, Carracedo A, Petrović I, Miyasaki JM, Abakumova I, Mäe MA, Raschperger E, Zatz M, Zschiedrich K, Klepper J, Spiteri E, Prieto JM, Navas I, Preuss M, Dering C, Janković M, Paucar M, Svenningsson P, Saliminejad K, Khorshid HRK, Novaković I, Aguzzi A, Boss A, le Ber I, Defer G, Hannequin D, Kostić VS, Campion D, Geschwind DH, Coppola G, Betsholtz C, Klein C, Oliveira JRM (2013) Mutations in the gene encoding PDGF-B cause brain calcifications in humans and mice. Nat Genet 45:1077-1082

50. Nicolas G, Pottier C, Maltête D et al (2013) Mutation of the PDGFRB gene as a cause of idiopathic basal ganglia calcification. Neurology 80:181-187
51. Yao XP, Cheng X, Wang C, Zhao M, Guo XX, Su HZ et al (2018) Biallelic mutations in MYORG cause autosomal recessive primary familial brain calcification. Neuron 98(6):1116-1123.e5

52. Chen Y, Fu F, Chen S et al (2018) Evaluation of MYORG mutations as a novel cause of primary familial brain calcification. Mov Disord 34(2):291-297

53. Ramos EM, Roca A, Chumchim N, Dokuru DR, Van Berlo V, De Michele G et al (2019) Primary familial brain calcification caused by a novel homozygous MYORG mutation in a consanguineous Italian family. Neurogenetics 20(2):99-102

54. Batla A, Tai XY, Schottlaender L, Erro R, Balint B, Bhatia KP (2017) Deconstructing Fahr's disease/syndrome of brain calcification in the era of new genes. Parkinsonism Relat Disord 37:1-10

55. Oliva M, Capaldo G, D'Amico A, Colavito D, Elefante A, Straccia G, Ugga L, Puoti G (2019) A novel SLC20A2 gene mutation causing primary familial brain calcification in an Ukrainian patient. Neurol Sci 40(6):1283-1285

56. Lamquet S, Ramos EM, Legati A, Coppola G, Hemelsoet D, Vanakker OM (2019) A likely pathogenic variant in the SLC20A2 gene presenting with progressive myoclonus. Ann Clin Transl Neurol 6(3):605-609

57. Gagliardi M, Morelli M, Iannello G, Colica C, Annesi G, Quattrone A (2017) A SLC20A2 mutation identified in an asymptomatic patient with brain calcification. J Neurol Sci 372:70-72

58. Paucar M, Almqvist H, Jelic V, Hagman G, Jörneskog G, Holmin S, Björkhem I, Svenningsson P (2017) A SLC20A2 gene mutation carrier displaying ataxia and increased levels of cerebrospinal fluid phosphate. J Neurol Sci 375:245-247

59. Wang C, Ma X, Xu X, Huang B, Sun H, Li L, Zhang M, Liu JY (2017) A PDGFB mutation causes paroxysmal nonkinesigenic dyskinesia with brain calcification. Mov Disord 32(7):1104-1106

60. Paucar M, Almqvist H, Saeed A, Bergendal G, Ygge J, Holmin S, Björkhem I, Svenningsson P (2016) Progressive brain calcifications and signs in a family with the L9R mutation in the PDGFB gene. Neurol Genet 2(4):e84

61. Mathorne SW, Sørensen K, Fagerberg C, Bode M, Hertz JM (2019) A novel PDGFRB sequence variant in a family with a mild form of primary familial brain calcification: a case report and a review of the literature. BMC Neurol 19(1):60

62. Wang C, Yao XP, Chen HT, Lai JH, Guo XX, Su HZ, Dong EL, Zhang QJ, Wang N, Chen WJ (2017) Novel mutations of PDGFRB cause primary familial brain calcification in Chinese families. J Hum Genet 62(7):697-701

63. López-Sánchez U, Nicolas G, Richard AC, Maltête D, Charif M, Ayrignac X et al (2019) Characterization of XPR1/SLC53A1 variants located outside of the SPX domain in patients with primary familial brain calcification. Sci Rep 9(1):6776

64. Guo XX, Zou XH, Wang C, Yao XP, Su HZ, Lai LL, Chen HT, Lai JH, Liu YB, Chen DP, Deng YC, Lin P, Lin HS, Hong BC, Yao QY, Chen XJ, Huang DQ, Fu HX, Peng JD, Niu YF, Zhao YY, Zhu XQ, Lu XP, Lin HL, Li YK, Liu CY, Huang GB, Wang N, Chen WJ (2019) Spectrum of SLC20A2, PDGFRB, PDGFB, and XPR1 mutations in a large cohort of patients with primary familial brain calcification. Hum Mutat 40(4):392-403

65. Nicolas G, Charbonnier C, de Lemos RR, Richard AC, Guillin O, Wallon D, Legati A, Geschwind D, Coppola G, Frebourg T, Campion D, de Oliveira JRM, Hannequin D, the collaborators from the French IBGC study Group (2015) Brain calcification process and phenotypes according to age and sex: lessons from SLC20A2, PDGFB and PDGFRB mutation carriers. Am J Med Genet B Neuropsychiatr Genet 168:586-594

66. Tadic V, Westenberger A, Domingo A, Alvarez-Fischer D, Klein C, Kasten M (2015) Primary familial brain calcification with known gene mutations: a systematic review and challenges of phenotypic characterization. JAMA Neurol 72:460-467 
67. Nicolas G, Pottier C, Charbonnier C et al (2103) Phenotypic spectrum of probable and genetically-confirmed idiopathic basal ganglia calcification. Brain 136(Pt 11):3395-3407

68. Manyam BV, Walters AS, Narla KR (2001) Bilateral striopallidodentate calcinosis: clinical characteristics of patients seen in a registry. Mov Disord 16:258-264

69. Chiriaco C, Novellino F, Salsone M, Gagliardi M, Morelli M, Quattrone A (2018) Neuropsychological heterogeneity in patients with primary familial brain calcification due to a novel mutation in SLC20A2. Neurol Sci 39(2):379-380

70. Ramos EM, Carecchio M, Lemos R, Ferreira J, Legati A, Sears RL et al (2018) Primary brain calcification: an international study reporting novel variants and associated phenotypes. Eur J Hum Genet 26(10):1462-1477

71. Grangeon L, Wallon D, Charbonnier C, Quenez O, Richard AC, Rousseau S, Budowski C, French PFBC study group et al (2019) Biallelic MYORG mutation carriers exhibit primary brain calcification with a distinct phenotype. Brain 142(6):1573-1586

72. de Oliveira DF, de Lemos RR, de Oliveira JR (2013) Mutations at the SLC20A2 gene and brain resilience in families with idiopathic basal ganglia calcification ("Fahr's disease"). Front Hum Neurosci $7: 420$

73. Westenberger A, Balck A, Klein C (2019) Primary familial brain calcifications: genetic and clinical update. Curr Opin Neurol. https://doi.org/10.1097/WCO.0000000000000712

74. Mu W, Tochen L, Bertsch C, Singer HS, Barañano KW (2019) Intracranial calcifications and dystonia associated with a novel deletion of chromosome 8p11.2 encompassing SLC20A2 and THAP1. BMJ Case Rep 12(5)

75. Knowles JK, Santoro JD, Porter BE, Baumer FM (2018) Refractory focal epilepsy in a paediatric patient with primary familial brain calcification. Seizure 56:50-52

76. Al-Azem H, Khan A (2012) Hypoparathyroidism. Best Pract Res Clin Endocrinol Metab 26(4):517-522

77. Maeda S, Fortes EM, Oliveira UM, Borba VC, Lazaretti-Castro M (2006) Hypoparathyroidism and pseudohypoparathyroidism. Arq Bras Endocrinol Metabol 50(4):664-673

78. Powers J, Joy K, Ruscio A, Lagast H (2013) Prevalence and incidence of hypoparathyroidism in the United States using a large claims database. J Bone Miner Res 28(12):2570-2576

79. Goswami R, Sharma R, Sreenivas V, Gupta N, Ganapathy A, Das S (2012) Prevalence and progression of basal ganglia calcification and its pathogenic mechanism in patients with idiopathic hypoparathyroidism. Clin Endocrinol 77:200-206

80. Asari R, Passler C, Kaczirek K, Scheuba C, Niederle B (2008) Hypoparathyroidism after total thyroidectomy: a prospective study. Arch Surg 143(2):132-137

81. Abate EG, Clarke BL (2017) Review of hypoparathyroidism. Front Endocrinol 7:172

82. Rastogi R, Beauchamp NJ, Ladenson PW (2003) Calcification of the basal ganglia in chronic hypoparathyroidism. J Clin Endocrinol Metab 88(4):1476-1477

83. Kim TW, Park IS, Kim SH, Lee KS, Kim YI, Kim JS (2007) Striopallidodentate calcification and progressive supranuclear palsy-like phenotype in a patient with idiopathic hypoparathyroidism. J Clin Neurol 3(1):57-61

84. Basak RC (2009) A case report of basal ganglia calcification - a rare finding of hypoparathyroidism. OMJ 24:220-222

85. Michels TC, Kelly KM (2013) Parathyroid disorders. Am Fam Physician 88(4):249-257

86. Zisimopoulou V, Siatouni A, Tsoukalos G, Tavernarakis A, Gatzonis S (2013) Extensive bilateral intracranial calcifications: a case of iatrogenic hypoparathyroidism. Case Rep Med 2013: 932184
87. Tsai DR, Huang SH, Lin SH (2013) Bilateral striopallidodentate calcinosis secondary to postsurgical hypoparathyroidism. BMJ Case Rep 13:2013

88. Agarwal R, Lahiri D, Biswas A, Mukhopadhyay J, Maity P, Roy MK (2014) A rare cause of seizures, parkinsonian, and cerebellar signs: brain calcinosis secondary to thyroidectomy. $\mathrm{N} \mathrm{Am} \mathrm{J} \mathrm{Med}$ Sci 6(10):540-542

89. Rizvi ANA, Beg M, Shamim MD (2012) Widespread intracranial calcification, seizures and extrapyramidal manifestations in a case of hypoparathyroidism. N Am J Med Sci 4:369-372

90. Sugawara Y (2016) Computed tomography anomalies associated with isolated hypoparathyroidism. Clin Case Rep 4:1205-1206

91. John DR, Suthar PP (2016) Radiological features of long-standing hypoparathyroidism. Pol J Radiol 81:42-45

92. Mendes EM, Meireles-Brandão L, Meira C, Morais N, Ribeiro C, Guerra D (2018) Primary hypoparathyroidism presenting as basal ganglia calcification secondary to extreme hypocalcemia. Clin Pract 8(1):1007

93. Al-Sous MW, Bohlega S, Al-Kawi MZ, Alwatban J, McLean DR (2004) Neurobrucellosis: clinical and neuroimaging correlation. AJNR Am J Neuroradiol 3:395-401

94. Mousa AM, Muhtaseb SA, Reddy RR, Senthilselvan A, A1Mudallal DS, Marafie AA (1987) The high rate of prevalence of CT-detected basal ganglia calcification in neuropsychiatric (CNS) brucellosis. Acta Neurol Scand 76:448-445

95. Liu J, Sulh MA, Zagzag D, Reuben R, Greco MA (1997) Disseminated calcification with predominant muscle and cerebral involvement in a child with acquired immunodeficiency syndrome: a case report. Pediatr Pathol Lab Med 4:593-600

96. Safriel YI, Haller JO, Lefton DR, Obedian R (2000) Imaging of the brain in the HIV-positive child. Pediatr Radiol 30:725-732

97. Lanjewar DN, Jain PP, Shetty CR (1998) Profile of central nervous system pathology in patients with AIDS: an autopsy study from India. AIDS 12(3):309-313

98. Safadi MA, Berezin EN, Farhat CK, Carvalho ES (2003) Clinical presentation and follow up of children with congenital toxoplasmosis in Brazil. Braz J Infect Dis 7(5):325-331

99. Reyes PF, Gonzalez CF, Zalewska MK, Besarab A (1986) Intracranial calcification in adults with chronic lead exposure. AJR Am J Roentgenol 146(2):267-270

100. Tonge JI, Burry AF, Saal JR (1977) Cerebellar calcification: a possible marker of lead poisoning. Pathology 9(4):289-300

101. Balani A, Golla N, Dey AK, Mahankali S, Seelam S (2016) Image of the month: intracranial calcifications due to chronic lead exposure. Clin Med (Lond) 16(5):494

102. Teo JG, Goh KY, Ahuja A, Ng HK, Poon WS (1997) Intracranial vascular calcifications, glioblastoma multiforme, and lead poisoning. AJNR Am J Neuroradiol 18(3):576-579

103. Illum $F$ (1980) Calcification of the basal ganglia following carbon monoxide poisoning. Neuroradiology 19:213-214

104. Souirti Z, Lahlou M, Ouali OE, Chtaou N, Aarab C, El Ghazouani F et al (2013) Neuropsychiatric systemic lupus erythematosus. Open J Rheumatol Autoimmune Dis 3:86-91

105. Jospeh FG, Scolding NJ (2010) Neurolupus. Pract Neurol 10:4-15

106. Raymond AA, Zariah AA, Samad SA, Chin CN, Kong NC (1996) Brain calcification inpatients with cerebral lupus. Lupus 5:123-128

107. Canas CA, Tobon GJ (2008) Multiple brain calcifications in a patient with systemic lupus erythematosus. Clin Rheumatol 27: S63-S65

108. Kaliterna DM, Radic M, Radic J, Kovacic V, Fabijanic D (2013) Massive cerebral calcifications (Fahr's disease) in a patient with systemic lupus erythematosus and no major neuropsychological abnormality. Isr Med Assoc J 15(10):654-655

109. Chang RS, Leung CYW, Leong HS (2015) Bilateral striatopallidodentate calcinosis associated with systemic lupus 
erythematosus: case report and review of literature. J Neurol Sci 358(1-2):518-519

110. Mantovani G, Romoli R, Weber G et al (2000) Mutational analysis of GNAS1 in patients with pseudohypoparathyroidism: identification of two novel mutations. J Clin Endocrinol Metab 85(11): $4243-4248$

111. Karikkineth AC, Scheibye-Knudsen M, Fivenson E, Croteau DL, Bohr VA (2017) Cockayne syndrome: clinical features, model systems and pathways. Ageing Res Rev 33:3-17

112. Laugel V (2013) Cockayne syndrome: the expanding clinical and mutational spectrum. Mech Ageing Dev 134(5-6):161-170

113. Koob M, Laugel V, Durand M, Fothergill H, Dalloz C, Sauvanaud F, Dollfus H, Namer IJ, Dietemann JL (2010) Neuroimaging in Cockayne syndrome. AJNR Am J Neuroradiol 31(9):1623-1630

114. Deepak Amalnath D, Mailankody S (2015) Teaching NeuroImages: Cockayne syndrome with extensive intracranial calcification. Neurology 84:e137

115. Goutières F (2005) Aicardi-Goutières syndrome. Brain and Development 27(3):201-206

116. Crow YJ, Hayward BE, Parmar R, Robins P, Leitch A, Ali M, Black DN, van Bokhoven H, Brunner HG, Hamel BC, Corry PC, Cowan FM, Frints SG, Klepper J, Livingston JH, Lynch SA, Massey RF, Meritet JF, Michaud JL, Ponsot G, Voit T, Lebon P, Bonthron DT, Jackson AP, Barnes DE, Lindahl T (2006) Mutations in the gene encoding the $3^{\prime}-5^{\prime}$ DNA exonuclease TREX1 cause Aicardi-Goutières syndrome at the AGS1 locus. Nat Genet 38(8):917-920

117. Rice G, Patrick T, Parmar R, Taylor CF, Aeby A, Aicardi J, Artuch R, Montalto SA, Bacino CA, Barroso B, Baxter P, Benko WS, Bergmann C, Bertini E, Biancheri R, Blair EM, Blau N, Bonthron DT, Briggs T, Brueton LA, Brunner HG, Burke CJ, Carr IM, Carvalho DR, Chandler KE, Christen HJ, Corry PC, Cowan FM, Cox H, D'Arrigo S, Dean J, de Laet C, de Praeter C, Déry C, Ferrie CD, Flintoff K, Frints SGM, Garcia-Cazorla A, Gener B, Goizet C, Goutières F, Green AJ, Guët A, Hamel BCJ, Hayward BE, Heiberg A, Hennekam RC, Husson M, Jackson AP, Jayatunga R, Jiang YH, Kant SG, Kao A, King MD, Kingston HM, Klepper J, van der Knaap MS, Kornberg AJ, Kotzot D, Kratzer W, Lacombe D, Lagae L, Landrieu PG, Lanzi G, Leitch A, Lim MJ, Livingston JH, Lourenco CM, Lyall EGH, Lynch SA, Lyons MJ, Marom D, McClure JP, McWilliam R, Melancon SB, Mewasingh LD, Moutard ML, Nischal KK, Østergaard JR, Prendiville J, Rasmussen M, Rogers RC, Roland D, Rosser EM, Rostasy K, Roubertie A, Sanchis A, Schiffmann R, Scholl-Bürgi S, Seal S, Shalev SA, Corcoles CS, Sinha GP, Soler D, Spiegel R, Stephenson JBP, Tacke U, Tan TY, Till M, Tolmie JL, Tomlin P, Vagnarelli F, Valente EM, van Coster RNA, van der Aa N, Vanderver A, Vles JSH, Voit T, Wassmer E, Weschke B, Whiteford ML, Willemsen MAA, Zankl A, Zuberi SM, Orcesi S, Fazzi E, Lebon P, Crow YJ (2007) Clinical and molecular phenotype of Aicardi-Goutieres syndrome. Am J Hum Genet 81(4): 713-725

118. Uggetti C, La Piana R, Orcesi S, Egitto MG, Crow YJ, Fazzi E (2009) Aicardi-Goutieres syndrome: neuroradiologic findings and follow-up. AJNR Am J Neuroradiol 30(10):1971-1976
119. Majamaa K, Moilanen JS, Uimonen S, Remes AM, Salmela PI, Kärppä M, Majamaa-Voltti KAM, Rusanen H, Sorri M, Peuhkurinen KJ, Hassinen IE (1998) Epidemiology of A3243G, the mutation for mitochondrial encephalomyopathy, lactic acidosis, and strokelike episodes: prevalence of the mutation in an adult population. Am J Hum Genet 63(2):447-454

120. Lorenzoni PJ, Werneck LC, Kay CS, Silvado CE, Scola RH (2015) When should MELAS (mitochondrial myopathy, encephalopathy, lactic acidosis, and stroke-like episodes) be the diagnosis? Arq Neuropsiquiatr 73(11):959-967

121. Nakamura M, Nakano S, Goto Y, Ozawa M, Nagahama Y, Fukuyama H, Akiguchi I, Kaji R, Kimura J (1995) A novel point mutation in the mitochondrial tRNA(Ser(UCN)) gene detected in a family with MERRF/MELAS overlap syndrome. Biochem Biophys Res Commun 214(1):86-93

122. Black GC, Perveen R, Bonshek R, Cahill M, Clayton-Smith J, Lloyd IC, McLeod D (1999) Coats' disease of the retina (unilateral retinal telangiectasis) caused by somatic mutation in the NDP gene: a role for norrin in retinal angiogenesis. Hum Mol Genet 8(11):2031-2035

123. Goutières F, Dollfus H, Becquet F, Dufier JL (1999) Extensive brain calcification in two children with bilateral Coats' disease. Neuropediatrics 30(1):19-21

124. Wu YW, Hess CP, Singhal NS, Groden C, Toro C (2013) Idiopathic basal ganglia calcifications: an atypical presentation of PKAN. Pediatr Neurol 49(5):351-354

125. Fasano A, Shahidi G, Lang AE, Rohani M (2017) Basal ganglia calcification in a case of PKAN. Parkinsonism Relat Disord 36: 98-99

126. Van Goethem G, Livingston JH, Warren D, Oojageer AJ, Rice GI, Crow YJ (2014) Basal ganglia calcification in a patient with betapropeller protein-associated neurodegeneration. Pediatr Neurol 51(6):843-845

127. Yoganathan S, Arunachal G, Sudhakar SV, Rajaraman V, Thomas M, Danda S (2016) Beta propellar protein-associated neurodegeneration: a rare cause of infantile autistic regression and intracranial calcification. Neuropediatrics 47(2):123-127

128. Shi CH, Zhang SY, Yang ZH, Yang J, Shang DD, Mao CY et al (2016) A novel RAB39B gene mutation in X-linked juvenile parkinsonism with basal ganglia calcification. Mov Disord 12:19051909

129. Tai XY, Batla A (2015) Fahr's disease: current perspectives. Orphan Drugs: Research and Reviews 5:43-49

130. Loeb JA (1998) Functional improvement in a patient with cerebral calcinosis using a bisphosphonate. Mov Disord 13(2):345-349

131. Oliveira JR, Oliveira MF (2016) Primary brain calcification in patients undergoing treatment with the biphosphanate alendronate. Sci Rep 6:22961

Publisher's note Springer Nature remains neutral with regard to jurisdictional claims in published maps and institutional affiliations. 